Pawet Czechowski ${ }^{1}$

\title{
Zasady prawa rolnego - stabilizacja czy ewolucja?
}

I. Minęło ponad trzydzieści lat, gdy na łamach „Państwa i Prawa”² z nieobecnym już wśród nas Profesorem Andrzejem Stelmachowskim sformułowaliśmy zasady prawa rolnego dla młodej wówczas, rozwijającej się dyscypliny nauk prawnych, jakim było prawo rolne. Dynamiczny rozwój prawa rolnego w poprzedniej formacji ustrojowej (także kontynuowany w gospodarce wolnorynkowej) wymagał sformułowania charakterystycznych zasad przewodnich tej dyscypliny nauk prawnych. Celem, jaki przyświecał autorom, było wykazanie, że w prawie rolnym ukształtowały się zasady prawa określające kierunkowe działania rozwiązań instytucjonalnych nowej dyscypliny prawnej, której „,korzenie” wywodzą się z prawa prywatnego i publicznego. Postawiliśmy sobie pytanie, jak zasady przewodnie prawa rolnego wpływają na system regulowanych stosunków społecznych. Staraliśmy się również odpowiedzieć na pytanie, które stawia sobie każda z teorii określonych działów gałęzi prawa, jak określone zasady prawne realizują określone uznawane wartości³

W wyniku analizy obowiązującego systemu prawa doszliśmy do wniosku, że zidentyfikowane przez nas zasady prawa rolnego są w sposób oczywisty powiązane z całym systemem prawa i tymi zasadami, które mają charakter uniwersalny dla wszystkich gałęzi prawa. Nie należy zapominać, że w analizowanym przez nas okresie nie było jeszcze bezsporne, że prawo rolne stanowi już ukształtowaną dyscyplinę prawa w ramach nauk prawnych ${ }^{4}$. Dlatego też teoretyczne wyodrębnienie zasad prawa rolnego zamykało metodologiczny proces wyodrębnienia prawa rolnego jako samodzielnej gałęzi prawa ${ }^{5}$. Nie ulegało również wątpliwości, że prawo rolne w analizowanym przez nas okresie (lata 1944-1979) tworzyło swoje zasady zgodnie z polityką rolną państwa i zasadami, jakie w różnych okresach przyświeca-

\footnotetext{
Uniwersytet Warszawski.

P. Czechowski, A. Stelmachowski, Zasady prawa rolnego, „Państwo i Prawo” 1979, z. 12, s. 30-38.

Por. zbliżone rozważania dotyczące prawa cywilnego w monografii A. Stelmachowskiego, Zarys teorii prawa cywilnego, Warszawa 1998, s. 12.

4 Por. R. Budzinowski, Problemy ogólne prawa rolnego. Przemiany podstaw legislacyjnych i koncepcji doktrynalnych, Poznań 2008, s. 225 i nast.

5 Por. A. Lichorowicz, Pojęcie i przedmiot prawa rolnego, (w:) A. Stelmachowski (red.), Prawo rolne, wyd. 5, Warszawa 2009, s. 31; R. Budzinowski, Pojęcie i przedmiot prawa rolnego, (w:) Prawo rolne, P. Czechowski (red.), Warszawa 2011, s. 36.
} 
ły tej polityce ${ }^{6}$. Pomiędzy celami polityki rolnej a zasadami prawa rolnego występuje bowiem swoiste sprzężenie zwrotne.

II. Upływ czasu, jak również przekształcenia ustrojowe, jakie dokonały się w Polsce po roku 1989 oraz członkostwo Polski w Unii Europejskiej, wymagają weryfikacji sformułowanych zasad prawa rolnego. Nadto obowiązujące uprzednio zasady ustrojowe państwa socjalistycznego stały się nieaktualne, takie jak m.in. sojusz robotniczo-chłopski czy też centralizm demokratyczny jako swoista metoda rządzenia państwem. Jednakże inne zasady, jak np. ustrojowa zasada praworządności, miały i mają zastosowanie we wszystkich gałęziach prawa również i obecnie zgodnie z konstytucyjną zasadą demokratycznego państwa prawa.

Uzyskanie przez Polskę członkostwa w Unii Europejskiej, w tym przyjęcie wszystkich reguł należących do acquis communautaire miało zapewnienie zdolności naszego kraju do korzystania ze statusu Unii Europejskiej ${ }^{7}$.

Polska, będąc członkiem Unii Europejskiej, zobowiązana została do stosowania polityk UE, w tym realizowania Wspólnej Polityki Rolnej. To właśnie zasady WPR stały się wyznacznikiem obecnych zmian polskiej polityki rolnej i wywarły istotny wpływ na prawo rolne. Sformułowane one zostały w roku 1957 w Traktacie Rzymskim o ustanowieniu Europejskiej Wspólnoty Gospodarczej. Określają one zasady wspólnotowego rynku rolnego ${ }^{8}$. Należą do nich:

a) zasada jedności rynku rolnego w powiązaniu ze swobodnym obrotem towarowym i kapitałowym także w sferze rolnictwa w ramach Wspólnot przy zniesieniu ceł wewnętrznych, kontyngentów towarowych oraz opłat przy zachowaniu reguł równego pochodzenia towarów z państw członkowskich Unii Europejskiej,

b) przyjęcie w handlu zagranicznym produktami i towarami rolnymi zasady preferencji dla towarów unijnych przed produktami i towarami importowanymi z krajów trzecich,

c) ujednolicenie mechanizmów interwencji rolnej na rynkach UE zarówno w odniesieniu do struktury cen krajowych, jak i dochodów rolniczych,

d) solidarnego współdziałania wszystkich państw członkowskich w finansowaniu Wspólnej Polityki Rolnej Unii Europejskiej.

Por. B. Jankowski, St. Prutis, Ewolucja pozycji właściciela indywidualnego gospodarstwa rolnego w wieloukładowym rolnictwie PRL, (w:) Ewolucja pozycji właściciela indywidualnego gospodarstwa rolnego w PRL, A. Stelmachowski, P. Czechowski (red.), Warszawa 1989, s. 9-63.

7 Por. S. Sołtysiński, Dostosowanie prawa polskiego do wymogów Układu Europejskiego, „Państwo i Prawo” 1996, z. 4-5, s. 32-33.

8 Por. przykładowo: P. Czechowski, Proces dostosowania polskiego prawa rolnego i żywnościowego do prawa Unii Europejskiej, Warszawa 2001, s. 13-14. 
III. Sformułowane w 1979 r. zasady polskiego prawa rolnego bazowały na obowiązującym, jak również historycznym stanie prawnym i przedstawiały się w sposób następujący:

1) zasada produkcyjności, a w jej ramach dalsze zasady: ochrony produkcyjności ziemi; ochrony gospodarstwa rolnego jako warsztatu pracy rolnika; stymulacji postępu techniczno-rolnego; specjalizacji i koncentracji,

2) zasada zróżnicowanego planowego sterowania rolnictwem przez państwo,

3) zasada kształtowania i ochrony zawodu rolnika,

4) zasada preferencji dla uspołecznionych form gospodarowania.

Analiza sformułowanych zasad prawa rolnego na tle obowiązującego prawa pozwala wskazać, co następuje: w nowych realiach gospodarki społeczno-rynkowej oraz członkostwa Polski w Unii Europejskiej jedynie część sformułowanych zasad wytrzymała próbę czasu. Część z nich natomiast ze względu na zmienione nowe realia ustrojowe już nie obowiązuje. Istota tych zmian związana jest $\mathrm{z}$ inną rolą państwa $i$ jego wpływem na proces oddziaływania na rolnictwo oraz szeroko pojmowane obszary wiejskie. Otóż państwo w ramach zasad i celów WPR, sformułowanych w prawie pierwotnym i pochodnym UE, w sposób interwencyjny oddziaływuje na rolnictwo i obszary wiejskie. Stosuje szereg instrumentów, w tym preferencji finansowych i innych metod oddziaływania, pozostawia możliwość wyboru i zastosowania ich przez rolników. W odniesieniu do interwencjonizmu socjalistycznego o charakterze nakazowo-rozdzielczym interwencjonizm funkcjonujący w Unii Europejskiej zakłada możliwość wyboru przez rolnika określonych preferencji w ramach prawnych mechanizmów WPR ${ }^{9}$. Możliwości tego wyboru występują w odniesieniu do produkcji rolnej oraz oddziaływania na obszary wiejskie.

Ad 1) Sformułowana zasada produkcyjności, a w jej ramach dalsze zasady pomimo zmian ustrojowych, niewątpliwie w znacznej części występuje nadal zarówno w ustawodawstwie krajowym, jak i wspólnotowym. Jednakże nie realizują już one ideologicznej zasady socjalistycznej rekonstrukcji rolnictwa czy też eliminowania „wyzysku człowieka przez człowieka”, gdyż realia gospodarki społeczno-rynkowej zakładają obowiązywanie określonych zasad konkurencji, w tym kontrolowanej pomocy publicznej - przy uwzględnieniu ochrony praw pracowników najemnych itp.

Przewijająca się w prawie krajowym i unijnym zasada produkcyjności nie wiąże się już z obowiązującą w socjalizmie zasadą planowego sterowania przez państwo rolnictwem, która miała prowadzić do utrzymania zasady „racjonalnego gospodarowania w ramach socjalistycznego planowania gospodarczego". Zasada

9 Por. P. Czechowski, Modele interwencjonizmu, (w:) Prawo rolne, pod red. P. Czechowskiego, Warszawa 2011, s. 64 i nast.; A. Jurewicz. Wspólna Polityka Rolna Unii Europejskiej, (w:) Prawo rolne, pod red. P. Czechowskiego, s. 81 i nast. 
produkcyjności w obecnie obowiązującym prawie krajowym i unijnym generalnie jest ściśle podporządkowana celom Wspólnej Polityki Rolnej. Występująca w ramach zasady produkcyjności ochrona produkcyjności ziemi poprzez obowiązujące ustawodawstwo poddana została istotnej modyfikacji. Ma ona za zadanie chronić produkcyjność gruntu rolnego (ziemi) jako określonego zasobu podlegającego ochronie przed oddziaływaniem czynników urbanizujących. Następuje to poprzez zespół norm prawnych regulujących ochronę gruntów oraz zagospodarowanie przestrzenne. W aspekcie ochrony zasobów środowiska normy te są ukierunkowane na ochronę produkcyjności ziemi rolniczej. W tym zakresie istota samej ochrony gruntów rolnych nie uległa generalnie zmianie za wyjątkiem planowego odłogowania gruntów, obowiązującego wcześniej w UE. Dokonano jej rozszerzenia o aspekt oddziaływania w ramach spektrum regulacji prawnych dotyczący ochrony gruntów rolnych w powiązaniu z rozwojem obszarów wiejskich oraz środowiskiem zgodnie $\mathrm{z}$ obowiązującą tendencją w prawie unijnym.

Zasada ochrony gospodarstwa rolnego w nowych warunkach ustrojowych została utrzymana w przepisach Konstytucji RP (art. 23), jak również w ustawach powszechnie obowiązujących. Należy jednak zaznaczyć, że np. w przepisach dotyczących dziedziczenia gospodarstw rolnych w wyniku wyroku Trybunału Konstytucyjnego z 31 stycznia 2001 r. ${ }^{10}$ została ona osłabiona na rzecz powszechności dostępu spadkobierców niebędących rolnikami do możliwości ubiegania się o dojście do masy spadkowej na zasadach ogólnych. Natomiast oddziaływanie prawa w sferze ochrony gospodarstwa rolnego jako warsztatu pracy nadal obowiązuje. Przykładu dostarczają odnośne regulacje kodeksu cywilnego dotyczące znoszenia współwłasności takich gospodarstw czy też przekazywania w ramach sukcesji generalnej gospodarstw następcom itp. Dotyczy to również regulacji szczegółowych odnośnie do umowy o przekazanie gospodarstwa rolnego następcy oraz regulacji prawnej dotyczącej kształtowania tzw. ustroju realnego.

Zasada stymulacji postępu techniczno-rolnego jest nadal obowiązująca w szczególności poprzez obowiązywanie szeregu aktów prawnych unijnych i krajowych regulujących problemy infrastrukturalne rolnictwa, wspomożona regulacjami dotyczącymi postępu biologicznego. Również poprzez stworzenie zespołu zadań programowych, zwłaszcza po uzyskaniu członkostwa w Unii Europejskiej, zasada ta uzewnętrznia się w ustawodawstwie w ramach wieloletniego krajowego Programu Rozwoju Obszarów Wiejskich (PROW) finansowanego ze środków pomocowych Unii Europejskiej ${ }^{11}$. Wspomnieć należy, że w ramach przekształceń ustrojowych zasada ta nie posiada już ideologicznego związku z ,,socjalistyczną rekonstrukcją wsi i rolnictwa" i związana jest ze sferą pomocy publicznej państwa dla rolnictwa. Sty-

10 Dz.U. Nr 11 poz. 91.

11 P. Wojciechowski, A. Niewiadomski, Program Rozwoju Obszarów Wiejskich, (w:) Prawo rolne, pod red. P. Czechowskiego, Warszawa 2011, s. 419 i nast. 
mulacja postępu biologicznego dotyczy hodowli zwierząt gospodarskich, nasiennictwa i hodowli roślin, elektryfikacji, melioracji, scalania gruntów, pomocy interwencyjnej dotyczącej wyposażenia technicznego gospodarstw rolnych oraz pomocy dla przetwórców produktów rolnych.

Wyodrębniona zasada specjalizacji i koncentracji produkcji w warunkach gospodarki rynkowej nie stanowi już zasady prawnej. Urynkowienia rolnictwa jako działu gospodarki rolnej nie wymagają stosowania wyspecjalizowanych regulacji prawnych w tym obszarze. Niekiedy jednak państwo w ramach programów pomocowych oddziaływuje na wyodrębnione kierunki produkcji.

Ad 2) Zasada zróżnicowanego sterowania rolnictwem przez państwo wraz ze zmianą ustroju społeczno-gospodarczego i rezygnacją z systemu planowania nakazowo-rozdzielczego w ustawodawstwie przestała definitywnie obowiązywać. Polska, wzorem Unii Europejskiej, nie wyzbyła się jednak środków pośredniego kierowania i wpływu na rolnictwo i obszary wiejskie. Dysponuje szeroką skalą instrumentów interwencyjnych oraz struktur organizacyjnych, m.in. agencji interwencyjno-płatniczych, które realizują cele i zadania Wspólnej Polityki Rolnej Unii Europejskiej.

Regulacja prawna tej problematyki jest wielopłaszczyznowa i oddziaływuje zarówno na sferę polityki rynkowej, jak i na rozwój obszarów wiejskich.

Obowiązujące regulacje prawne wprowadzane są zarówno na poziomie unijnym, jak również w ramach krajowego porządku prawnego. Dotyczą: kontroli wielkości produkcji rolnej, zapewnienia dochodów rolniczych na określonym poziomie, zwiększenia opłacalności eksportu produktów i towarów rolnych czy też ograniczenia napływu produktów i towarów rolnych z krajów trzecich ${ }^{12}$. Analizowany stan ustawodawstwa uprawnia zatem do postawienia tezy, że obowiązująca w ustawodawstwie poprzedniej formacji ustrojowej zasada zróżnicowanego sterowania rolnictwem przez państwo w realiach gospodarki rynkowej w wyniku rozwoju ustawodawstwa unijnego i krajowego została zastapiona zasadą interwencyjnego oddziaływania przez Unię Europejską i państwo narodowe na rolnictwo i obszary wiejskie zgodnie z celami i zadaniami WPR.

Ad 3) Zasada kształtowania i ochrony zawodu rolnika w wyniku rozwoju ustawodawstwa po roku 1989 doznała istotnej ewolucji. Dotyczy to zwłaszcza problemu kwalifikacji rolniczych, które pierwotnie w wyniku liberalizacji przepisów kodeksu cywilnego i aktów wykonawczych po roku 1989 zostały zniesione, a następnie w przepisach dotyczących kształtowania ustroju rolnego w formie daleko zmodyfikowanej przywrócone. Tendencje do przywrócenia kwalifikacji rolnych, które po- 
wiązane są z ograniczeniem dostępu do nabywania ziemi rolniczej przez osoby ich nieposiadające, odnajdujemy w ostatniej nowelizacji z dnia 16 września $2011 \mathrm{r}$. przepisów ustawy o gospodarowaniu nieruchomościami rolnymi Skarbu Państwa oraz ustawy o kształtowaniu ustroju rolnego ${ }^{13}$. Status związany z uprawnieniami socjalnymi rolników prywatnych nie uległ w wyniku przekształceń ustrojowych istotnym zmianom. Natomiast preferencje dla pracowników uspołecznionych form gospodarowania, zwłaszcza państwowych przedsiębiorstw gospodarki rolnej, wobec ich likwidacji przestały obowiązywać. Pracownicy tych przedsiębiorstw zatrudnieni w publicznych lub prywatnych spółkach rolnych prawa handlowego nabyli uprawnienia pracownicze na zasadach ogólnych. Pozostałe rolnicze spółdzielnie produkcyjne regulują status swoich członków lub pracowników w oparciu o status spółdzielcy lub spółdzielczy stosunek pracy lub stosunek umowny.

Ad 4) Zasada preferencji dla uspołecznionych form gospodarowania, obowiązując w szeregu regulacji prawnych przed rokiem 1989 jako obca systemowi gospodarki rynkowej bazującej na konstytucyjnej zasadzie równości i wolności gospodarczej, w nowej formacji ustrojowej przestała obowiązywać w wyniku uchylenia ustawodawstwa z tego zakresu.

IV. Dokonując przeglądu zasad prawa rolnego po ponad 30 latach od ich sformułowania w teorii prawa rolnego, stwierdzić należy, że podlegały one istotnej ewolucji. Wywołana ona została przekształceniami ustrojowymi po roku 1989, jak również uzyskaniem przez Polskę członkostwa w Unii Europejskiej.

Analizując problematykę zasad prawa rolnego, potwierdzić należy sformułowaną przez autorów tezę, że zdeterminowane są one poprzez politykę rolną oraz metody oddziaływania na rolnictwo.

Część z zasad zachowała swoją dotychczasową aktualność, część z nich realizuje nieco inne cele i zadnia niż uprzednio, a część w wyniku derogacji ustawodawstwa w związku ze zmianami ustrojowymi i członkostwem Polski w Unii Europejskiej utraciła swą aktualność i tym samym uznać je należy za nieobowiązujące. Przedstawiona powyżej analiza wskazuje, że zasady prawa rolnego będące podstawą dla wyodrębnienia samodzielnej dyscypliny prawnej, jaką jest prawo rolne, pomimo istotnej ewolucji ustawodawstwa oraz zmian ustrojowych, utrzymały się lub ewoluowały jako samodzielne zasady teoretyczno prawne ${ }^{14}$.

W tym miejscu wskazać należy na wyodrębnienie zasad prawa rolnego przez A. Lichorowicza, który do najistotniejszych zasad prawa rolnego zalicza: 1) zasadę ochrony trwałości warsztatu pracy producenta rolnego. W obrębie tej zasady można wyróżnić jej pewne, istotne aspekty: a) zasadę szczególnej ochrony interesów osób faktycznie prowadzących produkcję rolną wobec osób niebędących producentami rolnymi, b) zasadę pozytywnego oddziaływania na strukturę gruntową gospodarstw rolnych w celu jej modernizacji i zapewnienia gospodarstwom samowystarczalności ekonomicznej, c) zasadę kooperacji producentów rolnych. Zasada ta pod wpływem ustawodawstwa rolnego UE ponownie zaczyna nabierać znaczenia w naszym ustawodawstwie; 2) konstytucyjna zasadę szczególnej ochrony rodzinnego charakteru gospodarstw jako podstawy ustroju rolnego Polski (art. 23 
Reasumując powyższe rozważania, potwierdzić należy, że obowiązujące prawo rolne ustawodawstwo Unii Europejskiej oraz krajowe pozwala na sformułowanie nieco zmodyfikowanych zasad prawa rolnego i uszeregowanych ich według doniosłości regulacji prawnej. Należą do nich:

1) zasada interwencyjnego oddziaływania przez Unię Europejską i państwa narodowe na rolnictwo i obszary wiejskie zgodnie z celem Wspólnej Polityki Rolnej UE.

2) zasada produkcyjności, w tym stymulacji przez państwo postępu techniczno-rolnego i biologicznego.

3) zasada ochrony produkcyjności ziemi w ramach ochrony zasobów naturalnych w powiązaniu z zagospodarowaniem przestrzennym obszarów wiejskich.

4) zasada ochrony gospodarstwa rolnego jako warsztatu pracy rolnika oraz ochrony innych form gospodarowania ziemią.

Konstytucji); 3) zasadę ekonomicznego i socjalnego równouprawnienia ludności miejskiej i wiejskiej, a w szczególności: a) wprowadzenie gwarancji zrównania, a w każdym razie zbliżenia dochodów ludności miejskiej i producentów rolnych, b) uwzględnienie losowego charakteru produkcji rolnej i związanej z tym konieczności zwiększonej ochrony producenta rolnego przed jednostronnym ponoszeniem ryzyka produkcyjnego, c) zapewnienie producentom rolnym i ich rodzinom takiego samego stopnia ochrony socjalnej jak ludności miejskiej; 4) zasadę maksymalnej ochrony zdrowotnej konsumenta produktów rolnych; 5) zasadę harmonizacji regulacji struktury i procesów produkcyjnych w rolnictwie $z$ wymogami ochrony środowiska. W zwiazku z wstapieniem Polski do Unii Europejskiej autor powyższych zasad wskazuje, że ten katalog uległ wzbogaceniu o zasady zawarte w art. 33 TWE. Por. A. Lichorowicz, Pojęcie i przedmiot prawa rolnego. Miejsce prawa rolnego w polskim systemie prawa, (w:) A. Stlemachowski (red.), Prawo rolne, wyd. 5, s. 30-31. 


\section{Principles of agricultural law - stabilization or evolution?}

Key words: principle of agricultural law, political transformation, evolution of the principles

It has been more than thirty years since, in the pages of "Państwo i Prawo"15 (State and Law), together with Professor Andrzej Stelmachowski, who is not with us anymore, we formulated the principles of agricultural law for the young, developing discipline of Juridical Science, i.e. for the agricultural law. Dynamic development of the agricultural law in the previous political formation (also continued in the freemarket economy) required the formulation of specific guiding principles of this discipline of Juridical Science.

The passage of time, the political transformation that took place in Poland after 1989 as well as Poland's membership in the European Union require verification of the formulated principles of agricultural law.

Existing agricultural law as well as the legislation of the European Union and national legislation allow the formulation of new principles of agricultural law and ranking them according to the importance of legal regulation. They include:

1. The principle of intervention impact on agriculture and rural areas by the European Union and nation states in accordance with the objective of the EU Common Agricultural Policy.

2. The principle of productivity including the stimulation of technical and agricultural as well as biological progress by the state.

3. The principle of protection of the productivity of land within the frameworks of the protection of natural resources in conjunction with development of spatial rural areas.

4. The principle of protection of the farm as a farmer's workshop and of the protection of other forms of land management. 